ROCZNIKI HUMANISTYCZNE

Tom LXVIII, zeszyt $12-2020$

DOI: https://doi.org/10.18290/rh206812-7

BEATA BODZIOCH

\title{
PRZEOBRAŻENIA TEKSTOWE \\ W PIEŚNIACH ADWENTOWYCH I BOŻONARODZENIOWYCH ZAMIESZCZONYCH W ŚPIEWNIKU KOŚCIELNYM M.M. MIODUSZEWSKIEGO (1838) \\ ORAZ W ŚPIEWNIKU KOŚCIELNYM J. SIEDLECKIEGO (2015)
}

Polskie pieśni kościelne w ciągu wieków były notowane w wielu źródłach rękopiśmiennych i drukowanych, często jako dodatkowe śpiewy dołączane do innych ksiąg, np. graduałów, antyfonarzy, hymnarzy itp. (Wit 211). Zasadnicze znaczenie dla dziejów pieśni należy jednak przypisać zbiorom zwanym śpiewnikami. I choć ograniczenie badań nad twórczością pieśniową tylko do śpiewników zdaniem K. Mrowca byłoby dla twórczości tej bardzo niepełne (208), to jednak właśnie śpiewniki stanowią podstawowe źródło do studiów poświęconych tej kategorii śpiewów. Prace takie podejmowane były niejednokrotnie, a jednak dzieje polskich pieśni kościelnych dotąd ciągle są mało znane i dlatego stanowią interesujący materiał badawczy do przeprowadzenia dociekań komparatystycznych z wieloma śpiewnikami, począwszy od powstania jednego z pierwszych polskich śpiewników kościelnych z nutami (Mioduszewski 1838, dalej: Miod.) do ostatniej edycji śpiewnika ks. J. Siedleckiego (dalej: Siedl.2015). Mówiąc o Mioduszewskim 1838, mamy na myśli oczywiście zbiór, w którym znajduje się Śpiewnik wraz z dodatkami. Pierwszy $\mathrm{z}$ nich opublikowano $\mathrm{w}$ roku 1842, drugi i trzeci - w 1853. Autorka artykułu z szacunkiem przechowuje tenże zbiór. Dla zainteresowanych warto dodać,

Dr hab. BEATA BoDzIoch - Katolicki Uniwersytet Lubelski Jana Pawła II, Instytut Nauk o Sztuce, Katedra Etnomuzykologii i Hymnologii; adres do korespondencji: Al. Racławickie 14, 20-950 Lublin; e-mail: beata.bodzioch@kul.lublin.pl. ORCID: https://orcid.org/0000-0001-7574-9268.

Dr habil. BEATA BODZIOCH - The John Paul II Catholic University of Lublin, Institute of Art Studies, Department of the Ethnomusicology and Hymnology; address for correspondence: Al. Racławickie 14, 20-950 Lublin, Poland; e-mail: beata.bodzioch@kul.lublin.pl. ORCID: https://orcid.org/ 0000-0001-7574-9268. 
że jego reprint ukazał się drukiem w roku 2016. Niniejsze studium dotyczy dwóch wymienionych w tytule artykułu pozycji wyznaczających określoną klamrę czasową. Podczas wstępnego oglądu zebranych śpiewników okazało się, że przemiany językowe i muzyczne zaistniałe w ciągu niemal 200 lat, są wielorakie i niebanalne, potrzebują zatem znacznie więcej miejsca, niż przewidują to ramy jednego artykułu. Ponadto studiując wybrane do analizy zbiory, stało się oczywiste, iż w prezentowanym tekście nie uda się zamieścić kompletu badań obejmujących aspekty związane z językiem polskim i analizą muzykologiczną wszystkich pieśni. Postępując zatem systematycznie, uwagę skupiono na tekstach adwentowych i bożonarodzeniowych. Prace przyczynkarskie obejmujące tematykę pieśniową różnych części roku kościelnego w tych śpiewnikach podejmowali różni autorzy (np. Bodzioch 23-42; Szczeblewski 23-52). Jako narzędzie służące do analizy sporządzono tabelę obrazującą zmiany zachodzące w grupie badanych utworów.

Tabela 1. Pieśni wspólne dla Miod. i Siedl.2015

\begin{tabular}{|c|c|c|c|}
\hline L.p. & Tytul pieśni & 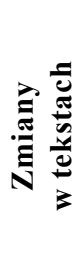 & 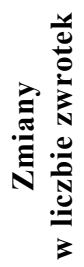 \\
\hline & ADWENTOWE & & \\
\hline 1. & Archanioł Boży & + & - \\
\hline 2. & Boże wieczny & + & - \\
\hline 3. & Głos wdzięczny & + & + \\
\hline 4. & Hejnał wszyscy & + & + \\
\hline 5. & Mądrości która & - & + \\
\hline 6. & Po upadku & - & + \\
\hline 7. & Spuśćcie nam na ziemskie & + & + \\
\hline \multirow[t]{2}{*}{8.} & Zdrowaś bądź Maryja & - & + \\
\hline & BOŻONARODZENIOWE & & \\
\hline 1. & A czemuż mój Jezus & - & + \\
\hline 2. & Ach, ubogi żłobie & + & + \\
\hline 3. & Ach, witajże pożądana & + & + \\
\hline 4. & Anioł pasterzom & + & - \\
\hline
\end{tabular}




\begin{tabular}{|c|c|c|c|}
\hline 5. & Archanioł Boży & + & - \\
\hline 6. & Bóg się rodzi, gwiazda & - & + \\
\hline 7. & Bóg się rodzi, moc & + & - \\
\hline 8. & Bóg się z Panny narodził & - & + \\
\hline 9. & Cieszmy się i pod niebiosy & - & + \\
\hline 10. & Dzieciątko się narodziło & + & + \\
\hline 11. & Gdy się Chrystus rodzi & + & - \\
\hline 12. & Jezu śliczny kwiecie & + & + \\
\hline 13. & Któż o tej dobie & + & + \\
\hline 14. & Mesyjasz przyszedł & + & - \\
\hline 15. & Na Boże Narodzenie & - & - \\
\hline 16. & Narodził się Jezus Chrystus & + & - \\
\hline 17. & Niepojęte dary & + & + \\
\hline 18. & Nowy Rok bieży & + & + \\
\hline 19. & Pan $\mathrm{z}$ nieba i $\mathrm{z}$ łona & + & + \\
\hline 20. & Pasterze mili & + & + \\
\hline 21. & Pójdźmy wszyscy & + & + \\
\hline 22. & Raduj się ziemio & - & + \\
\hline 23. & Rozkwitnęła się lilija & - & + \\
\hline 24. & Słyszę z nieba & + & + \\
\hline 25. & Tryumfy Króla & + & - \\
\hline 26. & W żłobie leży & + & + \\
\hline 27. & Witaj Jezu ukochany & + & + \\
\hline 28. & Witajmy Jezusa & + & + \\
\hline 29. & Z narodzenia Pana & - & + \\
\hline 30. & Zjawiło się nam & - & + \\
\hline
\end{tabular}

W tabeli znalazło się zatem 8 pieśni adwentowych i 30 bożonarodzeniowych. Z przeprowadzonych porównań wyłoniły się następujące problemy: zmiana szyku wyrazów, zamiana słów na inne, zastępowanie zdań czy wersów innymi zwrotami, redukcja lub dodawanie zwrotek.

\section{ZMIANA SZYKU WYRAZÓW}

Spośród 8 pieśni adwentowych wspólnych dla Miod. i Siedl.2015, tylko w jednej (Spuśćcie nam na ziemskie niwy) zauważono tego typu zabieg. Na 31 kolęd 
natomiast zmiany dotknęly $6 \mathrm{z}$ nich: Ach witajże pożadana, Aniol pasterzom mówit, Mesyjasz przyszedt, Witaj, Jezu ukochany, Witajmy Jezusa, W żłobie leży.

Jako przykład niech posłuży przedostatnia zwrotka pieśni Anioł pasterzom mówit. W Miod. brzmi ona następująco: „Słuchajcież Boga Ojca, jako go wam zaleca. Tenci (sic!) jest Syn najmilszy jedyny, wam w raju obiecany, Tego Wy słuchajcie". W Siedl. ta sama zwrotka ma następującą postać: „Słuchajcież Boga Ojca, jaka wam Go zaleca: ten Ci jest Syn najmilszy jedyny, w raju wam obiecany". Wydaje się, że nowsza wersja jest poprawniejsza gramatycznie. Poezja jednakże kieruje się własnymi prawami, a zwłaszcza poezja ściśle związana z melodią. Należałoby głębiej rozważyć konsekwencje tego typu zmian i dobrze się zastanowić, czy są one konieczne. Pierwotne brzmienia nie zmieniają znaczenia tekstu, sprawiają natomiast, że jest on bardziej „śpiewny”. Ponadto w pieśniach uświęconych czasem nieostrożnie wprowadzane zmiany powodują zbyteczne rozbicie ciągłość tradycji, wprowadzają u śpiewających poczucie niepewności. W sumie jednak oryginalny szyk wyrazów zachowano w około $80 \%$ badanych pieśni.

\section{ZAMIANA SŁÓW}

Ten zabieg redaktorzy Siedl. przeprowadzili w 4. następujących pieśniach adwentowych: Hejnat wszyscy (1 zamiana), Spuśćcie nam (1 zamiana), Archanioł Boży (2 zamiany), Głos wdzięczny (2 zamiany). Zamianę słów na inne dokonano też w dużej grupie kolęd (16): Ach, witajże (1 zamiana), Bóg się rodzi, moc truchleje (1 zamiana), Jezu, śliczny kwiecie (1 zamiana), Któż o tej dobie (1 zamiana), Nowy Rok bieży (1 zamiana), Pasterze mili (1 zamiana), W żłobie leży (1 zamiana), Witaj, Jezu ukochany (1 zamiana), Gdy się Chrystus rodzi (2 zamiany), Niepojęte dary (2 zamiany), Pójdźmy wszyscy (2 zamiany), Aniol pasterzom (3x), Ach ubogi żłobie (3x), Pan z nieba (3x), Mesyjasz przyszedt (4x), Tryumfy (6x).

Zauważamy, że w wielu przypadkach zastępowano staropolskie wyrazy, dziś być może niezrozumiałe, terminami współczesnymi, np. w pieśni $A r-$ chanioł Boży zwrot „sromieżliwa” zastąpiono słowem „świątobliwa”. Przeobrażenia słownictwa należą do natury każdego języka. Czy zasadna jest jednak manipulacja przy dawnych pieśniach? Są one przecież dziedzictwem narodowym. Kto nie rozumie, co znaczy „sromieżliwa”, może sprawdzić w Słowniku wyrazów staropolskich. Przełożenie go na „świątobliwa” nie oddaje pierwotnego znaczenia. Rezygnację z archaizmów można jednak zrozu- 
mieć. Ale dlaczego zmusza się wiernych, by np. w kolędzie Tryumfy Króla niebieskiego zamiast łatwego do zaśpiewania „by nas piekła pozbawił”, wykonywać męczące do wypowiedzenia „by nas z piekła wybawił”? Najtrudniej jednak zgodzić się z nic niewnoszącą ingerencją typu: „Pobudziły pasterzów (...) śpiewając”, na: „pobudziły pasterzów (...) śpiewaniem”.

\section{ZMIANY ZWROTÓW W RAMACH WERSÓW}

Niejednokrotnie zmianom uległy nie tylko pojedyncze słowa, ale całe zdania. Zjawisko to odnotowano w jednej pieśni adwentowej: Boże wieczny. Pierwotny tekst, który zamieścił Mioduszewski, brzmi następująco: „Amen zakrzykniem wdzięcznemi głosy, by nas Bóg świętymi (...)”. Natomiast w śpiewniku Siedleckiego, ten sam fragment ujęto nieco inaczej: „Amen krzykniem głosy swymi, by Pan Bóg ze świętymi (...)". Nie ma tutaj archaizmów ani ułomności gramatycznych. Jak więc uzasadnić interwencję któregoś z następców ks. Mioduszewskiego? Podobnie postąpiono w kilku kolędach: Dzieciątko się narodziło, Narodzit się Jezus Chrystus, Pan z nieba, Styszę z nieba muzyke, Tryumfy.

\section{LICZBA ZWROTEK}

Porównując teksty pieśni kościelnych, najczęściej zauważa się redukcję wcześniej istniejących zwrotek. Skrócenie tekstu wynika przypuszczalnie z przyczyn praktycznych. Współczesny człowiek nie jest skłonny do dłuższej refleksji, zanikła tradycja śpiewania w domu i poza nim. Funkcje liturgiczne pieśni są ograniczane czasem, chociaż nie zawsze musi tak być.

Druga przyczyna redukcji zwrotek leży w pominięciu tych o zbyt archaicznym brzmieniu. Faktycznie zdarzają się takie. Wydaje się jednak, że lepiej byłoby pominąc całą zwrotkę, niż poprawiać pojedyncze słowa. Za przykład niech posłuży fragment pieśni Boże wieczny, Boże żywy: „Weselcie się i dziateczki, Matki i cne panieneczki; Oto Panna Syna rodzi, Niech ta wieść wszystkich zachodzi”. Ten tekst w Siedl.2015 pominięto i postąpiono słusznie.

Biorąc pod uwagę nieodwracalną już chyba konieczność skracania tekstów pieśni, na plus redaktorów należy zapisać to, że redukcja zwrotek nie nastąpiła mechanicznie (np. pierwotnie było 12 strof, a pozostawiono 6 pierwszych), ale selekcji dokonano, wybierając strofy o najgłębszej treści teologicznej. Należały 
do nich często ostatnia lub dwie ostatnie zwrotki. W ten sposób postąpiono z następującymi pieśniami adwentowymi: Archanioł Boży (redukcja 5 zwrotek), Głos wdzięczny (12), Hejnat wszyscy (6), Mąrości, która (3), Po upadku (6), Spuście nam (8), Zdrowaś badź Maryja (8).

Za każdą ze zmian stoją indywidualne, ciekawe zjawiska. W tym kontekście na szczególną uwagę zasługuje pieśń Mądrości która. Składa się ona z tłumaczonych na język polski siedmiu tzw. Wielkich Antyfon „O”, śpiewanych w Nieszporach przed Magnificat w okresie poprzedzającym bezpośrednio Boże Narodzenie. Miod. uwzględnił wszystkie teksty, dodał jednak 3 końcowe zwrotki nienależące do tego zestawu. Współcześnie (Siedl.2015) opublikowano 7 „kanonicznych” zwrotek. Wydaje się, że w tym konkretnym przypadku, decyzja redaktorów była uzasadniona.

Kierując się tymi samymi względami, w pieśniach okresu Bożego Narodzenia, wyeliminowano z użytku wiele zwrotek należących pierwotnie do następujących kolęd: A czemuż mój Jezus (redukcja 2 zwrotek), Ach ubogi (1), Ach witajże (3), Bóg się rodzi, gwiazda wschodzi (6), Bóg się z Panny (1), Cieszmy się i pod niebiosy (1), Dzieciatko się narodziło (2), Jezu śliczny kwiecie (6), Któż o tej dobie (4), Niepojęte dary (1), Nowy Rok bieży (5), Pan z nieba (6), Pasterze mili (5), Pójdźmy wszyscy (4), Raduj się ziemio (5), Rozkwitnęła się lilija (8), Styszę z nieba (5), W żłobie leży (4), Witaj, Jezu ukochany (7), Witajmy Jezusa (4), Z narodzenia Pana (1), Zjawiło się nam (4).

W nielicznych przypadkach redaktorzy Siedl.2015 zdecydowali się na wprowadzenie zwrotek, których brakuje u Miod. Należą do nich dwie kolędy: Witaj Jezu ukochany (dodano 2 zwrotki), oraz Zjawiło się nam (1). W pierwszym przypadku Miod. ma 11 zwrotek. W Siedl.2015 mamy ich 4, z czego dwie pierwsze pochodzą od Miod., a dwie kolejne z Siedl.4. Kolęda Zjawiło się nam u Miod. ma 8 zwrotek, a Siedl.2015 ma ich 4. Zwrotka 3 rozpoczynająca się wersem „Pasterze zaraz prędko śpieszyli” nie figuruje w tekście Miod. W tym przypadku jednak redaktorzy nie zaznaczyli źródła tego tekstu.

Pełniejszy obraz przemian zachodzących w polskim repertuarze adwentowo-kolędowym ukaże tabela obejmująca tytuły pieśni znajdujące się w Miod. a pominięte przez Sied1.2015.

Tabela 2. Pieśni z Miod. pominięte w Sied1.2015

\begin{tabular}{|l|l|}
\hline \multicolumn{1}{|c|}{ Pieśni adwentowe } & \multicolumn{1}{c|}{ Pieśni na Boże Narodzenie } \\
\hline 1. Chwalmy Boga & 1. Alleluja, chwalmy \\
2. Posła do Panny & 2. Betlejem święte \\
3. Tobie nad pomysł & 3. Boże i Królu \\
\hline
\end{tabular}




\begin{tabular}{|l|l|}
\hline 4. Urząd zbawienia & 4. Bóg w Trójcy Świętej \\
& 5. Figurowana \\
& 6. Kiedy król Herod \\
& 7. Kiedy słyszę \\
& 8. Mamy przyjaciela \\
9. Narodzenie Chrysta \\
10. Narodził się pożądany \\
11. Nużeśmy chrześcijanie \\
12. O, błogosławiony \\
13. Obchodząc Jezusa \\
14. Pasterze bieżeli \\
15. Pasterze drzymali \\
16. Pasterze paśli \\
17. Przyjmij od nas \\
18. Szczęśliwa kolebko \\
19. W Betlejem mieście \\
20. Witaj Jezu nasz \\
21. Witajże Dzieciątko \\
22. Witam Cię, witam Jezu me kochanie \\
23. Wiwat dzisiaj \\
24. Wraz pochwalmy \\
25. Wspaniałości \\
26. Zawitaj Jezu \\
27. Zgińcie z oczu
\end{tabular}

W Siedl.2015 nie umieszczono 5 pieśni adwentowych i 27 kolęd. W Tabeli 3 ukazano natomiast repertuar pieśni dodanych w Siedl.2015. Okazuje się, że Siedl.2015 zawiera aż 21 ,nowych” śpiewów adwentowych i 28 kolęd:

Tabela 3. Pieśni dodane w Siedl.2015

\begin{tabular}{|l|l|}
\hline \multicolumn{1}{|c|}{ Pieśni adwentowe } & \multicolumn{1}{c|}{ Pieśni na Boże Narodzenie } \\
\hline Cz. 1 & 1. A wczora z wieczora \\
1. Błogosławiona & 2. Anieli w niebie śpiewają \\
2. Niech się radują & 3. Anioł Pański, otoczony światłością \\
3. Oto Pan Bóg przyjdzie & 4. Chryste, zbawienie ludzkości \\
4. Oto Pan przybywa & 5. Cicha noc, święte noc \\
5. Otwórzcie się szeroko & 6. Dlaczego dzisiaj \\
6. Pan jest blisko & 7. Do Betlejemu \\
7. Przybądź, Panie & 8. Do szopy, hej pasterze \\
\hline
\end{tabular}




\begin{tabular}{|c|c|}
\hline 8. Przyjdź, Panie Jezu & 9. Dzień to jest dziś wesela \\
\hline 9. Stwórco gwiaździstych przestworzy & 10. Dzisiaj chór aniołów \\
\hline 10. W tym świętym czasie & 11. Dzisiaj w Betlejem \\
\hline \multirow[t]{2}{*}{ 11. Z powagą przygotujcie } & 12. Jezusa narodzonego \\
\hline & 13. Mizerna cicha \\
\hline Cz. 2 & 14. Narodził się nam Zbawiciel \\
\hline 12.Córko Syjońska & 15. Niechaj będzie głośno wszędzie \\
\hline 13.Czekam na Ciebie & 16. O, Gwiazdo Betlejemska \\
\hline 14.Grzechem Adama & 17. O, Jezu nasz Zbawicielu \\
\hline 15.Gwiazdo morza & 18. Od bram dalekich \\
\hline 16. Matko Odkupiciela & 19. Przybądźcie tu z wiarą \\
\hline 17.Niebiosa rosę „spuśćcie” & 20. Przybieżeli do Betlejem \\
\hline 18. Niebiosa rosę ślijcie & 21. Przystąpmy do szopy \\
\hline 19.Oto Panna pocznie & 22. Serca ludzkie się radują \\
\hline 20.Pragniemy Ciebie & 23. Słysz! Już herold śpieszy \\
\hline \multirow[t]{5}{*}{ 21.Stworzycielu gwiazd świecących } & 24. Wesołą nowinę \\
\hline & 25. Wśród nocnej ciszy \\
\hline & 26. $\mathrm{Z}$ nieba wysokiego \\
\hline & 27. Za radosne Święta \\
\hline & 28. Zstąpiłeś z gwiazd dalekich \\
\hline
\end{tabular}

Przedstawione w artykule uwagi na temat tekstów polskich pieśni adwentowych i bożonarodzeniowych nie upoważniają do wyprowadzenia ogólnych i wiążących wniosków. Stanowią one jedynie zarys szerokiej problematyki związanej z procesami zmian zachodzących w polskich pieśniach kościelnych w ciągu niemal 200 ostatnich lat i to tylko na podstawie dwóch śpiewników. Niemniej przeprowadzone prace badawcze wskazują na stałe punkty uwzględniane przy dokonywaniu zmian. Po pierwsze daje się zauważyć uwspółcześnianie dawnych tekstów. Nie jest to praktyka nowa, gdyż już w połowie XX wieku wprowadzono wiele poprawek w Śpiewniku kościelnym, zredagowanym pod patronatem Episkopatu Polski (1956). Redaktorzy Sied1.2015 byli tego świadomi i nie uznawali za błąd ,uwspółcześnień słów tam, gdzie to było konieczne. Za konieczne zaś (...) uznaliśmy zastąpienie słów obecnie niezrozumiałych oraz tych, których dzisiejsze znaczeni rażąco odbiega od pierwotnego" (Kałamarz 10). Mimo tego trzeba zapytać, czy wszystkie wprowadzone poprawki mają pełne uzasadnienie? W tym kontekście jawi się problem ewentualnej kontynuacji tej tendencji w następnych wydaniach, co stwarza niebezpieczeństwo braku stabilności tekstów. Wreszcie nie jest bezzasadna troska o kształt tradycyjnych, wielowiekowych tekstów, zwłaszcza 
autorstwa wybitnych poetów, takich jak Jan Kochanowski, czy Franciszek Karpiński (Pawlak 503).

Trzeba także zauważyć, że w wydaniu jubileuszowym Śpiewnika kościelnego J. Siedleckiego (1928) redaktor W. Świerczek wprowadzał już zmiany i to nie tylko tekstowe, ale także melodyczne i rytmiczne. Za każdym jednak razem skrupulatnie je przy poszczególnych śpiewach odnotowywał. Tej praktyki zabrakło w kolejnych wydaniach śpiewnika, także w Siedl.2015. Ponadto $\mathrm{w}$ tymże wydaniu istnieje grupa pieśni oznaczonych jako zaczerpnięte z Miod., które w rzeczywistości tam się nie znajdują, np. Anieli w niebie.

Drugim bardzo ważnym zagadnieniem jest redukcja zwrotek w wielu pieśniach. Dokonano jej w siedmiu pieśniach adwentowych i aż w 22 kolędach. Redaktorzy Siedl.2015 do tej kwestii w ogóle się nie odnoszą. Dlatego trzeba hipotetycznie założyć, że głównymi przyczynami są: zbyt długie teksty, treści niezrozumiałe dla współczesnego wykonawcy, chęć dostosowania pieśni do użytku liturgicznego i wreszcie - czego nie można wykluczyć - indywidualne zdanie twórców śpiewnika. Szkoda jednak, że niektóre dokonane skróty burzą ustalony schemat pieśni, np. Zdrowaś badź Maryja, gdzie poszczególne zwrotki stanowią swoisty akrostych całego Pozdrowienia Anielskiego (Pawlak 503).

Aby dokonać całkowitej oceny zmian przeprowadzonych w pieśniach, trzeba, poza tekstami, koniecznie uwzględnić poprawki melodyczne i rytmiczne. Ta jednak problematyka czeka na kolejne studia komparatystyczne.

\section{BIBLIOGRAFIA}

Bodzioch, Beata. „Pieśni ku czci świętych Pańskich funkcjonujące w Śpiewniku ks. M.M. Mioduszewskiego oraz w wybranych edycjach Śpiewnika ks. J. Siedleckiego na przykładzie postaci św. Antoniego". Annales Lublinenses pro Musica Sacra, nr 10, 2019, ss. 23-42.

Bodzioch, Beata. „Śpiewy liturgii adwentu”. Liturgia Sacra, nr 2, 1999, ss. 345-364.

Garnczarski, Stanisław. „Pieśń Boże wieczny, Boże żywy. Tekst oraz jego warianty w źródłach drukowanych". Annales Lublinenses pro Musica Sacra, nr 2, 2011, ss. 59-70.

Garnczarski, Stanisław. Polska pieśń adwentowa w drukach od XVII do XX wieku. Biblos, 2014.

Kałamarz, Wojciech. „Przedmowa do XLI J. Siedleckiego”. Śpiewnik kościelny, red. Wojciech Kałamarz, Instytut Teologiczny Księży Misjonarzy, 2015, ss. 9-11.

Mrowiec, Karol. „Dokumentacja źródłowa polskich pieśni kościelnych - religijnych. Potrzeba i główne problemy." Ruch Biblijny i Liturgiczny, nr 3, 1982, ss. 201-210.

Pawlak, Ireneusz. „Śpiewnik kościelny, wyd. XLI, red. Wojciech Kałamarz, Kraków 2015, ss. 1422”. Liturgia Sacra, nr 2, 2015, ss. 499-505.

Siedlecki Jan, oprac. Śpiewnik kościelny, red. Wojciech Kałamarz, Instytut Teologiczny Księży Misjonarzy, 2015. 
Szczeblewski, Łukasz. „Ewolucja śpiewów ku czci Najświętszej Maryi Panny perspektywie przemian repertuarowych XIX-XX w. Studium na podstawie wybranych utworów w śpiewnikach ks. M.M. Mioduszewskiego i ks. J. Siedleckiego". Musica Ecclesiastica, nr 14, 2019, ss. 23-53.

Śpiewnik kościelny, red. Michał Marcin Mioduszewski, Kraków, Drukarnia S. Gieszkowskiego, 1838. Śpiewnik kościelny, red. Maria Nowogrodzka, Pallottinum, 1956.

Wit, Zbigniew. „Źródła polskich pieśni nabożnych”. Ruch Biblijny i Liturgiczny, nr 3, 1982, ss. 210-216.

\author{
PRZEOBRAŻENIA TEKSTOWE W PIEŚNIACH ADWENTOWYCH \\ I BOŻONARODZENIOWYCH ZAMIESZCZONYCH \\ W ŚPIEWNIKU KOŚCIELNYM M.M. MIODUSZEWSKIEGO (1838) \\ ORAZ W ŚPIEWNIKU KOŚCIELNYM J. SIEDLECKIEGO (2015)
}

\title{
Streszczenie
}

Podjęte badania komparatystyczne dotyczą repertuaru pieśni adwentowych i kolęd zawartego w dwóch wybranych śpiewnikach. W ciągu niemal 200 lat dokonano w pieśniach wielu zmian tekstowych. Obejmują one zmianę szyku, wymianę wielu słów na inne, zastępowanie nowym brzmieniem całych zwrotów i wersów oraz korekty w liczbie zwrotek. Zauważa się przede wszystkim tendencje do uwspółcześniania tekstów dawnych i redukcję strof. Zachodzące procesy nie są wynikiem naturalnej ewolucji języka, ale rezultatem ingerencji pojedynczych osób. Z wieloma skutkami zaistniałych interwencji trudno się zgodzić. Skalę przeobrażeń wybranej grupy pieśni i wiążące wnioski można będzie w sposób pełniejszy określić dopiero po przeprowadzeniu studiów porównawczych dotyczących melodyki i rytmiki pieśni.

Słowa kluczowe: pieśń kościelna; śpiewnik kościelny; tradycja; współczesność; kultura muzyczna.

\section{TEXT TRANSFORMATIONS IN ADVENT SONGS AND CHRISTMAS CAROLS PUBLISHED IN ŚPIEWNIK KOŚCIELNY BY M.M. MIODUSZEWSKI (1938) AND ŚPIEWNIK KOŚCIELNY BY J. SIEDLECKI (2015)}

\section{Summary}

The comparative research undertaken concerns the repertoire of Advent songs and Christmas carols contained in two selected songbooks. Over the course of almost 200 years many textual changes have been made to the songs. These include changing the order, exchanging many words for others, replacing whole phrases and verses with new wording, and corrections in the number of stanzas. The tendency to modernise old texts and to reduce stanza is particularly noticeable. These processes are not the result of the natural evolution of language, but the result of the intervention of individuals. It is difficult to agree with many of the consequences of these interventions. The scale of transformation of the selected song group and the conclusions can only be more fully determined after a comparative study of the melody and rhythm of the songs.

Key words: church song; church songbook; tradition; contemporary times; musical culture. 